\title{
Proteomics in rheumatology: the dawn of a new era
}

\section{Kamala Vanarsa* and Chandra Mohan}

Address: Department of Internal Medicine, Rheumatic Divisions Department, UT Southwestern Medical Center, 5323 Harry Hines Boulevard, Dallas, TX 75390-8884, USA

*Corresponding author: Kamala Vanarsa (kamala.vanarsa@utsouthwestern.edu)

FI000 Medicine Reports 2010, 2:87 (doi:10.3410/M2-87)

This is an open-access article distributed under the terms of the Creative Commons Attribution-Non Commercial License (http://creativecommons.org/licenses/by-nc/3.0/legalcode), which permits unrestricted use, distribution, and reproduction in any medium, provided the original work is properly cited. You may not use this work for commercial purposes.

The electronic version of this article is the complete one and can be found at: http://f 1000 .com/reports $/ \mathrm{m} / 2 / 87$

\begin{abstract}
Most rheumatic autoimmune diseases are complex in terms of their genetic origins and underlying pathogenic processes. Non-hypothesis-driven scanning platforms are adding novel insights to our understanding of these multifactorial diseases. This review summarizes the handful of recent proteomic studies that have been executed using samples from patients with rheumatoid arthritis, systemic lupus erythematosus, ankylosing spondylitis, osteoarthritis, or Sjogren's syndrome. The candidate biomarkers that have been uncovered in the reviewed studies have potential applications in diagnosis, prognosis, and theranostics. Though we are at the infancy of the proteomics era in rheumatology, the limited number of molecules uncovered thus far already hold promise. Ongoing research in proteomics holds tremendous potential for shaping how rheumatic diseases are diagnosed, prognosticated, and managed clinically over the coming years.
\end{abstract}

\section{Introduction and context}

Most rheumatic autoimmune diseases are complex in terms of their genetic origins and underlying pathogenic processes. Non-hypothesis-driven scanning platforms are adding novel insights to our understanding of these multi-factorial diseases. Transcriptomic profiling using DNA microarrays has been applied to the study of almost all rheumatic diseases. However, it is well accepted that encoded proteins (rather than mRNA) may better reflect cell function and disease. To date, only a handful of studies have examined rheumatic diseases through the prism of proteomics despite this approach emerging as one of the most powerful tools in biomarker discovery. Proteomic approaches include gel-based methods such as two-dimensional difference gel electrophoresis (2D DIGE) and modern mass spectrometric techniques. Since most biological samples in rheumatic diseases are body fluids and tissues that consist of complex mixtures of proteins, a combination of both classical and modern proteomic platforms are necessary for biomarker discovery and to identify specific post-translational modifications [1]. The studies utilizing these techniques that have discovered differentially expressed proteins associated with several rheumatic diseases constitute the focus of this review.

\section{Recent advances}

Several studies have recently identified several proteins that are differentially expressed in various rheumatic diseases. The studies listed in Table 1 were selected because they were all (a) unbiased proteomic profiling studies that were conducted using tissue isolated from human rheumatic diseases and uncovered (without any deliberate stimulation) one or more proteins as being differentially expressed in the disease state, and (b) studies where the protein identities were actually listed (as opposed to a series of $\mathrm{m} / \mathrm{z}$ values without actual protein identification). Excluded from Table 1 were proteomic studies carried out in cells stimulated in vitro and proteins that were not significantly altered in the particular rheumatic disease under investigation.

\section{Rheumatoid arthritis}

Thus far, eleven protein profiling studies have been conducted in rheumatoid arthritis (RA) and related diseases. Six have focused on serum and plasma while 
Table I. Protein markers in rheumatic diseases identified using proteomics

\begin{tabular}{|c|c|c|c|}
\hline $\begin{array}{l}\text { Rheumatic } \\
\text { disease }\end{array}$ & Sample used [Ref] & Differentially expressed proteins & $\begin{array}{l}\text { Validated by orthogonal approach and } \\
\text { independent study }\end{array}$ \\
\hline \multirow[t]{4}{*}{$\begin{array}{l}\text { Rheumatoid } \\
\text { arthritis }\end{array}$} & Serum $[2,21,22]$ & $\begin{array}{l}\text { AAT, CRP, GAPDH, SAA, SI00 proteins, } \\
\text { serotransferrin, TTR }\end{array}$ & AAT [23], CRP, SAA [3,4], SI00 proteins \\
\hline & Plasma $[3,4,19]$ & $\begin{array}{l}\text { Actin, apolipoprotein, calgranulin A, B, and C, } \\
\text { CRP, COLTI, SAA, SAAI, talin I, thymosin } \\
\beta 4, \text { PF4 }\end{array}$ & Apolipoprotein, COLTI, SAA [2,3,5], PF4 \\
\hline & $\begin{array}{l}\text { Synovial fluid and tissue } \\
{[5,6,21,23,24]}\end{array}$ & $\begin{array}{l}\text { Aldolase A, annexin, calcium-binding } \mathrm{SI} 00 \\
\text { proteins, calgranulin A (MRP8), cathepsin D, } \\
\text { CRP, ENOA, Ig K-chain, MnSOD, NGAL, } \\
\text { PRDX2, PRDX4, SOD2, TERA, TG2, TPI, } \\
\text { TXNDC5 }\end{array}$ & $\begin{array}{l}\text { Aldolase A [25], annexin, calcium-binding SI00 } \\
\text { proteins, calgranulin A (MRP8), cathepsin D, CRP } \\
\text { [26], ENOA, Ig k-chain, MnSOD, NGAL, PRDX2, } \\
\text { PRDX4, SOD2, TPI, TXNDC5 }\end{array}$ \\
\hline & Whole saliva [27] & $\begin{array}{l}\text { 6-PGDH, 14-3-3 protein, apolipoprotein A, } \\
\text { calgranulin A and B, E-FABP, GRP78/BiP, } \\
\text { PRDX5 }\end{array}$ & $\begin{array}{l}\text { 6-PGDH, I4-3-3 protein, apolipoprotein A, calgra- } \\
\text { nulin } A \text { and B, E-FABP, GRP78/BiP, PRDX5 }\end{array}$ \\
\hline Osteoarthritis & $\begin{array}{l}\text { Articular tissue [28], } \\
\text { cartilage [29], and } \\
\text { chondrocytes [18,30,3I] }\end{array}$ & $\begin{array}{l}\text { ADH, ADKI, ANNX-I, COLL-I and -VI, } \\
\text { ENOA, FR, Hsp } 27 \text {, HtrAI, KPYM, PEBP, PRDX3, } \\
\text { RNFI } 49 \text {, ROS, SOD2, SODM, TRAPI, TUB, } \\
\text { vimentin, Zn-RF }\end{array}$ & $\begin{array}{l}\text { ANNX-I, COLL-I and VI [II], Hsp 27, HtrAI }[9,10] \text {, } \\
\text { ROS, SOD2, TRAPI, vimentin [I2] }\end{array}$ \\
\hline \multirow{2}{*}{$\begin{array}{l}\text { Ankylosing } \\
\text { spondylitis }\end{array}$} & Serum $[32]$ & Haptoglobin precursor & Haptoglobin precursor \\
\hline & PBMC [33] & Keratin, PA28, SOD & SOD [34] \\
\hline $\begin{array}{l}\text { Systemic lupus } \\
\text { erythematosus } \\
\text { (SLE) }\end{array}$ & Urine $[14,15]$ & $\begin{array}{l}\text { Hepcidin-20 and -25, PGD2, renin, SAP, SOD, } \\
\text { total protease }\end{array}$ & $\begin{array}{l}\text { Hepcidin-20 and }-25, \text { PGD2, renin, SAP, SOD, total } \\
\text { protease }\end{array}$ \\
\hline \multirow[t]{2}{*}{$\begin{array}{l}\text { Sjogren's } \\
\text { syndrome (SS) }\end{array}$} & Saliva [35-37] & $\begin{array}{l}\alpha \text {-amylase, } \alpha \text {-defensin, amylase precursor, } \beta \text {-actin, } \\
\text { calgranulin A and B, carbonic anhydrase, cystatin } \\
\text { precursor, FABP, GSH, IgG receptor, keratin, } \\
\text { LEI, PIP, serum albumin, vitamin D }\end{array}$ & $\begin{array}{l}\alpha \text {-amylase, } \alpha \text {-defensin }[17], \beta \text {-actin, calgranulin } A \text { and } \\
B \text { [38], carbonic anhydrase [39], cystatin precursor, } \\
\text { keratin [37] }\end{array}$ \\
\hline & Salivary gland [I7] & $\alpha$-defensin, calmodulin & $\alpha$-defensin, calmodulin \\
\hline
\end{tabular}

Listed in the third column of Table I are all proteins that were upregulated (in bold font) or downregulated (in regular font) in disease samples compared with healthy controls (or disease control), as listed in the original reports. The criteria used to decide whether or not a study was included in Table I are detailed in the text. The differentially expressed proteins that have been validated using orthogonal approaches and/or in independent studies are listed in the final column. 6-PGDH, 6-phosophogluconate dehydrogenase; AAT, alpha I-antitrypsin; ADH, alcohol dehydrogenase; ADKI, adenylate kinase isoenzyme I; ANNX-I, annexin-I; COLL-I, collagen type I; COLTI, coactosin-like I; CRP, C-reactive protein; E-FABP, epidermal fatty-acid binding protein; ENOA, alpha enolase; FABP, fatty-acid binding protein; FR, flavin reductase; GAPDH, glyceraldehyde 3-phosphate dehydrogenase; GRP78/BiP, 78-kDa glucose-regulated protein precursor (also known as binding immunoglobulin protein); GSH, glutathione; Ig k-chain, immunoglobulin kappa chain; IgG receptor, immunoglobin G receptor; KPYM, pyruvate kinase isozymes MI/M2; LEl, leukocyte elastase inhibitor; MnSOD, manganese superoxide dismutase; MRP8, myloid-related protein 8; NGAL, neutrophil gelatinase-associated lipocalin; PA28, protein activator of the 20 S proteasome; PBMC, peripheral blood mononuclear cell; PEBP, phosphatidylethanolamine-binding protein; PF4, platelet factor 4; PGD2, prostaglandin D2; PIP, prolactin-inducible protein; PRDX2, peroxiredoxin-2; RNFI49, RING finger protein 149; ROS, reactive oxygen species; SAA, serum amyloid A; SAP, serum amyloid P component; SOD, superoxide dismutase; SODM, mitochondrial superoxide dismutase, TERA, transitional endoplasmic reticulum ATPase; TG2, transglutaminase 2; TPI, triose phosphate isomerase; TRAPI, tumor necrosis factor receptor-associated protein I; TTR, transthyretin; TUB, Tubby protein homolog; TXNDC5, thioredoxin domain-containing protein 5; Zn-RF, zinc RING finger protein.

five were conducted using materials isolated from the synovium. Using high-throughput mass spectrometric techniques, these studies have uncovered approximately 33 different proteins that are differentially expressed in RA, of which four have been independently confirmed by other investigators (Table 1). Of particular interest are the elevations in SAA (serum amyloid A) [2-5], SOD (superoxide dismutase) and TPI (triose phosphate isomerase) $[6,7]$ because they have been reported in multiple studies in plasma and synovial tissue, as is evident from Table 1. In addition to uncovering potential disease biomarkers, proteomics can also yield insights into the molecular pathways impacted by therapy. A recent example is the identification of the nuclear factor-kappa B pathway as being differentially expressed in RA patients treated with anti-tumor necrosis factor-alpha (anti-TNFo) [8]. Hence, the observed changes in various inflammatory, antiinflammatory, and antioxidant proteins not only yield clues regarding the pathogenesis of this disease but may also aid clinicians in gauging disease prognosis and monitoring response to treatment.

\section{Osteoarthritis}

A total of five different proteomic studies have been conducted in osteoarthritis (OA). Of these studies, two have focused on articular cartilage while three have examined articular chondrocytes. Even though these studies used gel electrophoresis for resolving the proteins, 
the combined use of classical and advanced mass spectrometric techniques have enabled the identification of approximately 20 proteins as being differentially expressed in OA (Table 1). Of these 20 proteins, the elevations in HtrA1 [9,10], collagen [11], and vimentin [12] were confirmed by independent studies (Table 1). The upregulation of these molecules again sheds light on the pathogenic cascades underlying this disease and underscores the functional importance of physiological processes aimed at maintaining sound articular structure and function.

\section{Ankylosing spondylitis}

Only three proteomic studies have been conducted in ankylosing spondylitis (AS) to date, of which two have examined serum and plasma while the most recent study was performed using peripheral blood mononuclear cells. In addition to using advanced mass spectrometric techniques, Gao and colleagues [13] employed a metabolomic platform to identify approximately seven different markers that were differentially expressed in AS. Clearly, validation and independent confirmation of these findings is warranted, and until further validation and information becomes available, it is difficult to conjecture the biological and clinical importance of the identified molecules.

\section{Systemic lupus erythematosus}

Although serum and plasma samples from systemic lupus erythematosus (SLE) patients have not been systematically scanned, two groups have examined urine from lupus nephritic subjects. One report found that the urinary proteins overexpressed in lupus nephritis include hepcidin [14], while the other reported an association with SAP (serum amyloid P component), PGD2 (prostaglandin D2), SOD, renin, and protease [15]. Elevated urinary hepcidin and PGD2 have also been confirmed by independent reports [16]. The presence of these molecules in high amounts in SLE patients indicates their potential role in either disease progression (e.g., protease and SAP) or disease modulation (e.g., SOD) in nephritis. Additionally, monitoring the levels of these molecules may also help clinicians predict the disease course of these devastating ailments.

\section{Sjogren's syndrome}

Recently, four different proteomic studies have been performed in Sjogren's syndrome (SS). Three studied saliva while one examined the salivary gland proteome [17]. Collectively, 16 different proteins have been identified in SS (of which seven have been independently confirmed by multiple reports) and include elevations in $\beta$-actin, $\alpha$-defensin, keratin, calmodulin, and calgranulin, as detailed in Table 1. A significant increase in levels of these proteins may reflect underlying acinar cell damage (e.g., keratin) and inflammation (e.g., calmodulin and calgranulin) that may mediate the pathogenesis of this disease.

\section{A technology in evolution}

Proteomic approaches are constantly expanding our ability to quantify changes in protein expression and modification in an unbiased fashion for a given biological sample. Current limitations include our lack of ability to extend comprehensive coverage to encompass the entire proteome to include even the low-abundance proteins with sufficient degrees of quantification and reproducibility. Encouragingly, the technology used has been steadily evolving over the past decade. For example, until recently, 2D gel electrophoresis (2DGE) was the most powerful proteomic profiling technique for both protein identification and quantitation in clinical samples. But this platform fails to detect proteins with extreme $\mathrm{pH}$ values, high and low molecular weights, proteins with low copy numbers, and those with hydrophobic domains. However, recently, liquid chromatography-based mass spectrometric (LC-MS) techniques have begun to exercise their dominance in the field, although they are more costly and technologically intensive. Present day technologies allow for more accurate quantitation of the differentially expressed proteins. Additionally, quantification of proteins in samples from different subjects, different stages of disease, or different treatment conditions can be achieved by using protein tags such as iTRAQ (isobaric tag for relative and absolute quantitation), ICAT (isotope-coded affinity tag) and cICAT (cleavable ICAT), which significantly reduce sample-to-sample variation and time-point variation. Although most of the shortcomings of 2DGE can be alleviated, there is still room for improvement with LC-MS-based platforms as the field marches towards attaining total coverage of the entire proteome at an affordable cost.

\section{Implications for clinical practice}

Candidate biomarkers identified using high-throughput proteomic platforms have potential applications in diagnosis, prognosis, and theranostics. Though we are in the infancy of the proteomics era in rheumatology, the limited number of molecules uncovered thus far already hold promise. Some of these molecules yield insights into the disease process. For example, in RA and OA, elevated annexin 1 may serve to inhibit inflammatory cytokines such as interleukin (IL)-1, TNFo, and IL-6 [7]. Overexpression of annexin-1 in these disease settings may indicate an increased 'attempt' to suppress inflammation. Similarly the upregulation of MnSOD (manganese superoxide dismutase) and PRDX2 (peroxiredoxin 2) may function to suppress oxidative stress, underscoring their 
attractiveness as therapeutic targets. Likewise, the significant upregulation of $\alpha$-enolase and TPI in synovial fibroblasts in RA and OA alludes to the potential diagnostic and prognostic value of these two biomarkers [7]. Along the same line, the elevated TNF receptorassociated protein 1 (TRAP1) molecule in patients with OA may also serve to protect cells from oxidative-stressinduced apoptosis, since TRAP1 is a mitochondrial protein belonging to the Hsp90 family of molecular chaperones [18].

Some markers may have a role in predicting disease and also in monitoring response to treatment. One example of this in the field of lupus is hepcidin. In patients with SLE, urinary hepcidin-20 has been reported to increase 4 months pre-flare and return to baseline at renal flare. In the same study, hepcidin-25 was noted to decrease at renal flare and return to baseline 4 months post-flare. Since hepcidin-20 increases pre-flare, it has the potential to be a biomarker for predicting impending renal failure. Additionally, because hepcidin-25 levels were modulated by treatment, it also has biomarker potential for monitoring treatment response [14]. However, these predictions need to be validated in independent patient cohorts. In a more recent study, it was reported that urinary protease in lupus nephritis was renal in origin and correlated well with concurrent renal pathology activity [15]. Clearly, this is a rapidly evolving field, and the most predictive biomarkers for foreboding disease flares and predicting treatment response await systematic elucidation.

A related class of biomarkers is those that can predict which patients might respond best to a given therapeutic regime. One example of this is evident in the field of RA; it appears that monitoring the levels of plasma apolipoprotein-1 may indicate which RA patients are likely to respond to infliximab treatment, while assaying PF4 (platelet factor 4) levels may indicate which RA patients may not respond [19]. Once again, this observation needs to be validated, and the several additional markers reported in RA also need to be tested for their theranostic potential. Extrapolating from these early studies, the ongoing research in proteomics holds tremendous potential for shaping how rheumatic diseases are diagnosed, prognosticated, and managed in a clinical setting in the coming years.

\section{Looking to the future}

Thus far, there has been a dearth of quantitative proteomic studies in the field of rheumatology. As discussed above, this is now being remedied through several novel technologies. With the employment of more quantitative proteomic platforms, rheumatologists are likely to succeed in discovering an increasing panel of potential disease markers with a greater degree of sensitivity. The challenge at that point would be to validate the identified markers using orthogonal platforms and to establish the specificity of the molecule for the various rheumatic diseases. Being able to predict the disease course and dictate the optimal treatment regime simply by examining the patient's fluids would transform how rheumatology is practiced.

\section{Abbreviations}

2D DIGE, two-dimensional difference gel electrophoresis; 2DGE, two-dimensional gel electrophoresis; AS, ankylosing spondylitis; IL, interleukin; LC-MS, liquid chromatography-based mass spectrometry; OA, osteoarthritis; PGD2, prostaglandin D2; RA, rheumatoid arthritis; SAP, serum amyloid P component; SLE, systemic lupus erythematosus; SOD, superoxide dismutase; SS, Sjogren's syndrome; TNFa, tumor necrosis factor-alpha; TPI, triose phosphate isomerase; TRAP1, tumor necrosis factor receptor-associated protein 1.

\section{Competing interests}

The authors declare that they have no competing interests.

\section{References}

I. Lalvani A, Meroni PL, Millington KA, Modolo ML, Plebani M, Tincani A, Villalta D, Doria A, Ghirardello A: Recent advances in diagnostic technology: applications in autoimmune and infectious diseases. Clin Exp Rheumatol 2008, 26(Suppl 48):S62-6.

2. Naishiro $Y$, Suzuki C, Kimura M, Yamamoto $M$, Takahashi $H$, Sohma H, Hori T, Shinomura Y, Kokai Y, Imai K: [Plasma analysis of rheumatoid arthritis by SELDI]. Nihon Rinsho Meneki Gakkai Kaishi 2007, 30:145-50.

3. Zheng X, Wu SL, Hincapie M, Hancock WS: Study of the human plasma proteome of rheumatoid arthritis. J Chromatogr A 2009, | 2 | 6:3538-45.

4. Jin EH Shim SC, Kim HG, Chae SC, Chung HT: Polymorphisms of COTLI gene identified by proteomic approach and their association with autoimmune disorders. Exp Mol Med 2009, 4I:354-6I.

5. Mallya RK, Vergani D, Tee DE, Bevis L, de Beer FC, Berry $H$, Hamilton ED, Mace BE, Pepys MB: Correlation in rheumatoid arthritis of concentrations of plasma $\mathrm{C} 3 \mathrm{~d}$, serum rheumatoid factor, immune complexes and $\mathrm{C}$-reactive protein with each other and with clinical features of disease-activity. Clin Exp Immunol 1982, 48:747-53.

6. Chang $X$, Cui $Y$, Zong $M$, Zhao $Y$, Yan X, Chen $Y$, Han J: Identification of proteins with increased expression in rheumatoid arthritis synovial tissues. J Rheumatol 2009, 36:872-80.

7. Bo GP, Zhou LN, He WF, Luo GX, Jia XF, Gan CJ, Chen GX, Fang YF, Larsen PM, Wu J: Analyses of differential proteome of human synovial fibroblasts obtained from arthritis. Clin Rheumatol 2009, 28:191-9.

8. Sekigawa I, Yanagida M, Iwabuchi K, Kaneda K, Kaneko H, Takasaki Y, Jung G, Sone S, Tanaka Y, Ogawa H, Takamori K: Protein biomarker analysis by mass spectrometry in patients with rheumatoid arthritis receiving anti-tumor necrosis factoralpha antibody therapy. Clin Exp Rheumatol 2008, 26:26I-7.

9. Grau S, Richards PJ, Kerr B, Hughes C, Caterson B, Williams AS, Junker $U$, Jones SA, Clausen T, Ehrmann $M$ : The role of human HtrAI in arthritic disease. J Biol Chem 2006, 28 I:6I24-9. 
10. Chamberland A, Wang E, Jones AR, Collins-Racie LA, LaVallie ER, Huang Y, Liu L, Morris EA, Flannery CR, Yang Z: Identification of a novel HtrAl-susceptible cleavage site in human aggrecan: evidence for the involvement of HtrAl in aggrecan proteolysis in vivo. J Biol Chem 2009, 284:27352-9.

\section{FI000 Factor 6}

Evaluated by Ingrid Meulenbelt 08 Dec 2009

II. Tallheden T, Karlsson C, Brunner A, Van Der Lee J, Hagg R, Tommasini R, Lindahl A: Gene expression during redifferentiation of human articular chondrocytes. Osteoarthritis Cartilage 2004, I 2:525-35.

12. Blain EJ, Gilbert SJ, Hayes AJ, Duance VC: Disassembly of the vimentin cytoskeleton disrupts articular cartilage chondrocyte homeostasis. Matrix Biol 2006, 25:398-408.

13. Gao P, Lu C, Zhang F, Sang P, Yang D, Li X, Kong H, Yin P, Tian J, Lu X, Lu A, Xu G: Integrated GC-MS and LC-MS plasma metabonomics analysis of ankylosing spondylitis. Analyst 2008, 133:|2| 4-20.

14. Zhang $X$, Jin $M$, Wu H, Nadasdy T, Nadasdy G, Harris N, GreenChurch K, Nagaraja H, Birmingham DJ, Yu CY, Hebert LA, Rovin BH: Biomarkers of lupus nephritis determined by serial urine proteomics. Kidney Int 2008, 74:799-807.

15. Wu TF, Fu Y, Brekken D, Yan M, Zhou XJ, Vanarsa K, Deljavan N, Ahn C, Putterman C, Mohan C: Urine proteome scans uncover total urinary protease, prostaglandin D synthase, serum amyloid $P$, and superoxide dismutase as potential markers of lupus nephritis. J Immunol 2010, 184:2183-93.

FI000 Factor 6

Evaluated by Jennifer Anolik 3I Aug 2010

16. Rovin $\mathrm{BH}, \mathrm{X}$ Zhang: Biomarkers for lupus nephritis: the quest continues. Clin J Am Soc Nephrol 2009, 4:1858-65.

17. Hjelmervik TO, Jonsson R, Bolstad Al: The minor salivary gland proteome in Sjogren's syndrome. Oral Dis 2009, I 5:342-53.

18. Ruiz-Romero C, Calamia V, Mateos J, Carreira V, MartínezGomariz M, Fernández M, Blanco FJ: Mitochondrial dysregulation of osteoarthritic human articular chondrocytes analyzed by proteomics: a decrease in mitochondrial superoxide dismutase points to a redox imbalance. Mol Cell Proteomics 2009, 8:172-89.

19. Trocme C, Marotte H, Baillet A, Pallot-Prades B, Garin J, Grange L, Miossec P, Tebib J, Berger F, Nissen MJ, Juvin R, Morel F, Gaudin P: Apolipoprotein A-I and platelet factor $\mathbf{4}$ are biomarkers for infliximab response in rheumatoid arthritis. Ann Rheum Dis 2009, 68: 1328-33.

20. Low JM, Chauhan AK, Gibson DS, Zhu M, Chen S, Rooney ME, Ombrello MJ, Moore TL: Proteomic analysis of circulating immune complexes in juvenile idiopathic arthritis reveals disease-associated proteins. Proteomics Clin Appl 2009, 3:829-40.

21. Liao H, Wu J, Kuhn E, Chin W, Chang B, Jones MD, O'Neil S, Clauser KR, Karl J, Hasler F, Roubenoff R, Zolg W, Guild BC: Use of mass spectrometry to identify protein biomarkers of disease severity in the synovial fluid and serum of patients with rheumatoid arthritis. Arthritis Rheum 2004, 50:3792-803.

22. Scott LJ, Evans EL, Dawes PT, Russell GI, Mattey DL: Comparison of IgA-alphal-antitrypsin levels in rheumatoid arthritis and seronegative oligoarthritis: complex formation is not associated with inflammation per se. $\mathrm{Br} J$ Rheumatol 1998, 37:398-404.

23. Katano M, Okamoto K, Arito M, Kawakami $Y$, Kurokawa MS, Suematsu N, Shimada S, Nakamura H, Xiang Y, Masuko K, Nishioka K, Yudoh K, Kato T: Implication of granulocytemacrophage colony-stimulating factor induced neutrophil gelatinase-associated lipocalin in pathogenesis of rheumatoid arthritis revealed by proteome analysis. Arthritis Res Ther 2009, II:R3.

24. Tilleman K, Van Beneden K, Dhondt A, Hoffman I, De Keyser F, Veys E, Elewaut D, Deforce D: Chronically inflamed synovium from spondyloarthropathy and rheumatoid arthritis investigated by protein expression profiling followed by tandem mass spectrometry. Proteomics 2005, 5:2247-57.

25. Serada S, Fujimoto M, Takahashi T, He P, Hayashi A, Tanaka T, Hagihara K, Yamadori T, Mochizuki M, Norioka N, Norioka S, Kawase I, Naka T: Proteomic analysis of autoantigens associated with systemic lupus erythematosus: Anti-aldolase $\mathbf{A}$ antibody as a potential marker of lupus nephritis. Proteomics Clin Appl 2007, I:|85-9|.

26. Walters MT, Stevenson FK, Goswami R, Smith JL, Cawley MI: Comparison of serum and synovial-fluid concentrations of beta-2-microglobulin and C-reactive protein in relation to clinical-disease activity and synovial inflammation in rheumatoid arthritis. Ann Rheum Dis 1989, 48:905-II.

27. Giusti L, Baldini C, Ciregia F, Giannaccini G, Giacomelli C, De Feo F, Delle Sedie A, Riente L, Lucacchini A, Bazzichi L, Bombardieri S: Is GRP78/BiP a potential salivary biomarker in patients with rheumatoid arthritis? Proteomics Clin Appl 2010, 4:3 I5-24.

28. Wu J, Liu W, Bemis A, Wang E, Qiu Y, Morris EA, Flannery CR, Yang Z: Comparative proteomic characterization of articular cartilage tissue from normal donors and patients with osteoarthritis. Arthritis Rheum 2007, 56:3675-84.

29. Guo D, Tan W, Wang F, Lv Z, Hu J, Lv T, Chen Q, Gu X, Wan B, Zhang Z: Proteomic analysis of human articular cartilage: identification of differentially expressed proteins in knee osteoarthritis. Joint Bone Spine 2008, 75:439-44.

30. Lambrecht S, Verbruggen G, Verdonk PC, Elewaut D, Deforce D: Differential proteome analysis of normal and osteoarthritic chondrocytes reveals distortion of vimentin network in osteoarthritis. Osteoarthritis Cartilage 2008, 16:163-73.

31. Lambrecht S, Dhaenens M, Almqvist F, Verdonk P, Verbruggen G, Deforce D, Elewaut D: Proteome characterization of human articular chondrocytes leads to novel insights in the function of small heat-shock proteins in chondrocyte homeostasis. Osteoarthritis Cartilage 2010, 18:440-6.

32. Liu J, Zhu P, Peng J, Li K, Du J, Gu J, Ou Y: Identification of diseaseassociated proteins by proteomic approach in ankylosing spondylitis. Biochem Biophys Res Commun 2007, 357:53I-6.

33. Wright $C$, Edelmann M, diGleria $K$, Kollnberger $S$, Kramer $H$, McGowan S, McHugh K, Taylor S, Kessler B, Bowness P: Ankylosing spondylitis monocytes show upregulation of proteins involved in inflammation and the ubiquitin proteasome pathway. Ann Rheum Dis 2009, 68:1626-32.

34. Stanek A, Cieślar G, Romuk E, Kasperczyk S, Sieroń-Stołtny K, Birkner E, Sieroń A: Decrease in antioxidant status of plasma and erythrocytes from patients with ankylosing spondylitis. Clin Biochem 2010, 43:566-70.

35. Giusti L, Baldini C, Bazzichi L, Ciregia F, Tonazzini I, Mascia G, Giannaccini G, Bombardieri S, Lucacchini A: Proteome analysis of whole saliva: a new tool for rheumatic diseases-the example of Sjogren's syndrome. Proteomics 2007, 7:1634-43.

36. Peluso G, De Santis M, Inzitari R, Fanali C, Cabras T, Messana I, Castagnola M, Ferraccioli GF: Proteomic study of salivary peptides and proteins in patients with Sjogren's syndrome before and after pilocarpine treatment. Arthritis Rheum 2007, 56:2216-22.

37. Fleissig Y, Deutsch O, Reichenberg E, Redlich M, Zaks B, Palmon A, Aframian DJ: Different proteomic protein patterns in saliva of Sjogren's syndrome patients. Oral Dis 2009, 15:6I-8.

38. Giusti L, Bazzichi L, Baldini C, Ciregia F, Mascia G, Giannaccini G, Del Rosso M, Bombardieri S, Lucacchini A: Specific proteins identified in whole saliva from patients with diffuse systemic sclerosis. J Rheum 2007, 34:2063-69.

39. Ryu OH, Atkinson JC, Hoehn GT, Illei GG, Hart TC: Identification of parotid salivary biomarkers in Sjogren's syndrome by surface-enhanced laser desorption/ionization time-of-flight mass spectrometry and two-dimensional difference gel electrophoresis. Rheumatology (Oxford) 2006, 45:1077-86. 